\title{
PENGARUH MODEL PEMBELAJARAN KOOPERATIF TIPE STAD DENGAN MEMPERTIMBANGKAN KEMAMPUAN AWAL TERHADAP KEMAMPUAN MENULIS TEKS BERITA SISWA KELAS VIII SMP NEGERI 24 JAMBI
}

\author{
Firman Tara \\ Program Studi Pendidikan Bahasa dan Sastra Indonesia \\ Fakultas Keguruan dan Ilmu Pendidikan \\ Universitas Batanghari
}

\begin{abstract}
This research aims to: (1) Describe the ability to write news text students are taught using STAD type cooperative learning model and students are taught using convensional learning; (2) Describe the ability to write high-priority student-language text texts that are taught using STAD-type cooperative models and are taught using convensional learning; (3) Describe the ability to write low-priority student-language text texts that are taught using STAD-type cooperative models and are taught using convensional learning, and (4) Describe the interaction of cooperative learning model type STAD and initial ability to the ability to write news text of students of class VIII SMP Negeri 24 Jambi. The type of this research is quantitative with $2 \times 2$ factorial experimental designs. The population of the research is the students of class VIII SMP Negeri 24 consisting of 6 classes. The sample of this research is class VIIIA for experiment class with 40 students and class VIIIB for control class with 38 students. Sample determination is determined by purposive sampling technique. The data of students' news text writing capability was obtained using performance test and analyzed using two ways Anova test. Based on the results of this study, it can be concluded that STAD type cooperative learning model affects the ability to write student news text. The effect can be explained as follows. First, the ability to write news texts of students taught using STAD type cooperative learning model is better than students taught using convensional learning. Second, the ability to write high-priority students' text news taught using STAD type cooperative models is better than students taught using convensional learning. Third, the ability to write low-priority students' text taught using STAD type cooperative models is better than students being taught using convensional learning. Fourth, there is no interaction between STAD type cooperative learning model and initial ability to write news text skills of students of class VIII SMP Negeri 24 Jambi.
\end{abstract}

Keywords: writing news texts, cooperative learning, convensional learning 


\section{PENDAHULUAN}

Menulis merupakan kegiatan mengungkapkan atau mengekspresikan gagasan, ide, pendapat maupun perasaan yang dimiliki seseorang. Hal ini sesuai dengan pendapat Semi (2007:14) yang menyatakan bahwa menulis merupakan suatu proses kreatif memindahkan gagasan ke dalam lambang-lambang tulisan. Untuk terampil dalam menulis, tidak cukup hanya dengan mempelajari pengetahuan tentang teori menulis saja. melainkan harus dimulai dengan banyak belajar dan latihan.

Keterampilan menulis tidak dapat dipisahkan dari proses pembelajaran. Keterampilan menulis diberikan dalam pembelajaran formal dengan tujuan agar siswa dapat menuangkan gagasan, pikiran, pendapat dan kisah tentang kehidupan orang lain. Selain itu, pembelajaran menulis diberikan dengan maksud agar siswa dapat memahami bahasa Indonesia dan menggunakannya dengan tepat dan kreatif untuk berbagai tujuan. Salah satu bentuk menggunakan bahasa Indonesia yang tepat dan kreatif dapat diwujudkan melalui kegiatan menulis.

Salah satu kompetensi menulis yang harus dikuasai siswa dalam pembelajaran bahasa Indonesia di sekolah menengah pertama adalah kemampuan menulis teks berita. Kompetensi ini diajarkan pada kelas VIII, khususnya pada standar kompetensi (SK) mengungkapkan infomasi dalam bentuk rangkuman, berita, slogan/poster. Standar kompetensi ini dijabarkan menjadi tiga kompetensi dasar (KD) yang salah satunya adalah kompetensi dasar (12.2) menulis teks berita secara singkat, padat, dan jelas.

Pembelajaran menulis teks berita diberikan dengan tujuan agar siswa mampu menulis teks berita menggunakan kalimat efektif, mampu menulis teks berita dengan menggunakan unsur $5 \mathrm{~W}+1 \mathrm{H}$ (apa, di mana, kapan, siapa, mengapa, dan bagaimana) secara lengkap, dan mampu menulis teks berita dengan ejaan dan tanda baca secara tepat. Hal ini sesuai dengan pendapat Chaer (2010: 17) yang menjelaskan bahwa berita harus mengungkapkan unsur $5 \mathrm{~W}$ dan $1 \mathrm{H}$, yang mencakup what (apa yang terjadi), who (siapa yang terlibat dalam kejadian), why (mengapa kejadian itu terjadi), where (di mana kejadian itu terjadi), when (kapan terjadinya), dan how (bagaimana kejadiannya). Selain itu, pembelajaran diberikan dengan tujuan siswa mampu merumuskan judul yang tepat dan menarik dan juga menulis berita dengan menggunakan pola piramida terbalik.

Berdasarkan observasi yang dilakukan, pada umumnya siswa mengalami kendala dalam menulis teks berita. Siswa belum mampu menulis teks berita dengan baik. Menurut Nurgiyantoro (2014:427) "Dalam pandangan umum selama ini kompetensi menulis sulit untuk dikuasai". Hal ini bisa dilihat dari teks berita yang dihasilkan, di antaranya masih terdapat kata yang berlebihan penggunaannya, sehingga menjadikan kalimat berita tidak efektif. Siswa juga belum mampu menulis dengan menggunakan unsur berita $(5 \mathrm{~W}+1 \mathrm{H})$ secara lengkap. Hal itu dikarenakan siswa belum memahami maksud dari unsurunsur berita tersebut. Selain itu, siswa juga belum mampu merumuskan judul dengan tepat dan menarik serta siswa belum sepenuhnya mampu menulis teks erita dengan menggunakan metode piramida terbalik. Hal itu dikarenakan siswa belum melalui tahap latihan yang sifatnya terus menerus sehingga kemampuan menulis teks berita siswa masih rendah.

$$
\text { Menindaklanjuti informasi }
$$

tersebut, selanjutnya dilakukan wawancara dengan siswa siswa kelas VIII SMP Negeri 24 Jambi. Berdasarkan wawancara tersebut diperoleh informasi bahwa metode pembelajaran yang 
diterapkan guru masih secara tradisional dan jarang menggunakan model-model pembelajaran di antaranya model pembelajaran kooperatif. Guru memberikan materi dengan penjelasan secara langsung dan siswa hanya mendengarkan. Kemudian guru memberikan pertanyaan dan tes untuk mengukur kemampuan siswa dalam memperoleh pengetahuan yang diberikan. Hal ini menyebabkan siswa sering berperan pasif dalam pembelajaran sehingga banyak siswa yang tidak mampu menyelesaikan masalah pada materi pelajaran yang diberikan oleh guru.

Berdasarkan permasalahan di atas, untuk meningkatkan kemampuan menulis teks berita diperlukan adanya pembelajaran yang menarik. Pembelajaran yang mampu meningkatkan semangat dan kreativitas siswa. Hal tersebut dapat dilakukan dengan menerapkan model pembelajaran. Model pembelajaran yang sesuai dengan materi. Model pembelajaran mampu membuat siswa bekerja sama menyelesaikan masalah dengan baik, sehingga hasil belajar yang maksimal dapat tercapai.

Berdasarkan identifikasi di atas, model kerja sama dalam pembelajaran yang tepat digunakan pada siswa kelas VIII SMP Negeri 24 Jambi adalah model pembelajaran kooperatif tipe STAD. Model pembelajaran kooperatif tipe STAD adalah model kooperatif yang sederhana dan sangat cocok digunakan bagi guru yang jarang atau bahkan yang tidak pernah menggunakan model pembelajaran kooperatif. Hal ini sejalan dengan pendapat Slavin (2005:143) yang menyatakan "STAD merupakan salah satu model pembelajaran kooperatif yang paling sederhana dan merupakan model yang paling baik untuk permulaan bagi para guru yang baru menggunakan pendekatan kooperatif'.

Berdasarkan penjelasan di atas, maka penelitian ini bertujuan untuk: (1)
Mendeskripsikan kemampuan menulis teks berita siswa yang diajar menggunakan model pembelajaran kooperatif tipe STAD dan siswa yang diajar menggunakan pembelajaran konvensional siswa kelas VIII SMP Negeri 24 Jambi; (2) Mendeskripsikan kemampuan menulis teks berita siswa berkemampuan awal tinggi yang diajar menggunakan model kooperatif tipe STAD dan siswa berkemampuan awal tinggi yang diajar menggunakan pembelajaran konvensional siswa kelas VIII SMP Negeri 24 Jambi; (3) Mendeskripsikan kemampuan menulis teks berita siswa berkemampuan awal rendah yang diajar menggunakan model kooperatif tipe STAD dan siswa yang berkemampuan awal rendah yang diajar menggunakan pembelajaran konvensional siswa kelas VIII SMP Negeri 24 Jambi; (4) Mendeskripsikan interaksi antara model pembelajaran kooperatif tipe STAD dan kemampuan awal terhadap kemampuan menulis teks berita siswa siswa kelas VIII SMP Negeri 24 Jambi.

\section{METODE}

Jenis penelitian ini adalah penelitian quasi experiment atau eksperimen semu karena variabel penelitian tidak mungkin untuk dikontrol secara penuh. Seperti yang dinyatakan Sugiyono (2010:77), "Quasi experiment tidak dapat berfungsi sepenuhnya untuk mengontrol variabel-variabel yang mempengaruhi pelaksanaan eksperimen". Eksperimen dilakukan di kelas yang menggunakan seluruh subjek dalam kelompok belajar untuk diberi perlakuan. Desain penelitian ini terdiri dari satu kelompok eksperimen dan satu kelompok kontrol.

Kelompok eksperimen adalah kelompok siswa yang menerima perlakuan dengan menerapkan model pembelajaran kooperatif tipe STAD. Sementara kelompok kontrol adalah kelompok siswa 
yang menerima perlakuan dengan menerapkan pembelajaran konvensional. Rancangan penelitian yang digunakan dalam penelitian ini adalah desain factorial 2x2. Pemilihan model ini disesuaikan dengan data yang diharapkan, yaitu perbedaan kemampuan menulis teks berita sebagai akibat dari perlakuan yang diberikan.

Populasi dalam penelitian ini adalah seluruh siswa kelas VIII SMP Negeri 24 Jambi yang terdiri dari 6 kelas dengan jumlah mahasiswa 232 orang. Hal ini sesuai dengan pendapat Sugiyono (2010:80) yang menyatakan bahwa "Populasi merupakan wilayah generalisasi yang terdiri dari objek/subjek yang mempunyai kualitas dan karakteristik tertentu yang ditetapkan oleh peneliti untuk dipelajari dan kemudian ditarik kesimpulannya".

Sampel terdiri dari dua kelompok, yaitu kelas VIIIA selaku kelompok eksperimen dan kelas VIIIB selaku kelompok kontrol. Menurut Sudjana dan Ibrahim dan Sudjana (2009:85), "Sampel adalah sebagian dari populasi terjangkau yang memiliki sifat yang sama dengan populasi”. Teknik pengambilan sampel dilakukan menggunakan teknik purposive sampling. Usman dan Akbar (2006:186) menyatakan bahwa teknik purposive sampling digunakan apabila anggota sampel yang dipilih secara khusus berdasarkan tujuan penelitiannya

Instrumen yang digunakan untuk mengumpulkan data dalam penelitian ini terdiri dari dua tes. Tes pertama digunakan untuk mengetahui Kemampuan awal siswa, sedangkan tes kedua dilakukan untuk mengukur kemampuan menulis teks berita. (1) tes kemampuan awal, tes kemampuan awal yaitu tes yang diberikan kepada siswa sebelum pembelajaran. Tes ini dilakukan untuk mengukur kemampuan awal siswa tinggi atau rendah, baik di kelas eksperimen maupun kelas kontrol. Tes yang diberikan berhubungan dengan indikator. (2) tes unjuk kerja, tes adalah tes yang dilakukan untuk mengukur kemampuan siswa dalam menulis teks berita. Untuk menentukan tes yang akan digunakan dalam penelitian ini harus disesuaikan terlebih dahulu dengan jenis dan tujuan penelitian.

Teknis analisis data tes kemampuan awal siswa dilakukan sebagai berikut. Pertama, memeriksa jawaban yang telah diisi oleh siswa. Kedua, menjumlahkan jawaban yang benar. Ketiga, mengurutkan skor siswa mulai dari yang tertinggi sampai yang terendah. Keempat, membagi siswa menjadi tiga kelompok, 27\% kelompok tinggi, 46 kelompok sedang, dan 27\% kelompok rendah (Sudjana, 2010:139). Kelima, memisahkan kelompok tinggi dengan kelompok rendah dari kelompok sedang, karena pada penelitian ini, kemampuan awal hanya menggunakan siswa berkemampuan awal tinggi dan rendah. Sedangkan teknis analisis data tes unjuk kerja menulis teks berita siswa dilakukan sebagai berikut.

a. Membaca teks berita yang telah ditulis siswa.

b. Mengoreksi teks berita yang telah ditulis siswa berdasarkan rubrik penilaian.

c. Mengubah skor yang diperoleh siswa menjadi penilaian acuan patokan (PAP). Rumus yang digunakan adalah rumus persentase menurut Nurgiyantoro (2011:264) sebagai berikut.

$\mathrm{N}=\frac{S M}{S I} x S M a x$

Keterangan:

$\mathrm{N}=$ Tingkat penguasaan

$\mathrm{SM}=$ Skor yang diperoleh

SI $\quad=$ Skor Ideal

Smax = Skala yang digunakan

d. Menyajikan nilai yang diperoleh ke dalam tabel distribusi frekuensi.

e. Melakukan uji hipotesis. Sebelum uji hipotesis dilakukan, terlebih dahulu 
dilakukan uji prasyarat analisis, yaitu uji normalitas dan uji homogenitas.

\section{HASIL PENELITIAN DAN PEMBAHASAN}

a. Kemampuan Menulis Teks Berita Siswa yang Diajar Menggunakan Model Kooperatif Tipe STAD dan Pembelajaran Konvensional

Hasil pengujian hipotesis pertama mengungkapkan bahwa secara keseluruhan, kemampuan menulis teks berita siswa yang diajar dengan model pembelajaran kooperatif tipe STAD lebih baik daripada kemampuan menulis teks berita siswa yang diajar dengan pembelajaran konvensional. Hal ini terlihat dari pengujian hipotesis yang menunjukkan bahwa pada taraf nyata $0,05, \mathrm{t}_{\text {hitung }}=50,468>\mathrm{t}_{\text {tabel }} 1,681$. Hasil tersebut menunjukkan bahwa $t_{\text {hitung }}>t_{\text {tabel }}$ yang berarti $\mathrm{H}_{0}$ ditolak dan $\mathrm{H}_{1}$ diterima. Untuk lebih jelasnya bisa dilihat pada tabel berikut.

Tabel 1. Hasil Uji Hipotesis Tes Kemampuan Menulis Teks Berita Siswa yang Diajar Menggunakan Model Kooperatif Tipe STAD dan Pembelajaran Konvensional

\begin{tabular}{|l|c|c|c|c|c|}
\hline \multicolumn{1}{|c|}{ Kelas } & $\mathbf{N}$ & $\overline{\boldsymbol{x}}$ & $\mathbf{t}_{\text {hitung }}$ & $\mathbf{D f}$ & $\mathbf{t}_{\text {tabel }}$ \\
\hline Eksperimen & 22 & 70,81 & \multirow{2}{*}{50,468} & \multirow{2}{*}{40} & 1,681 \\
\cline { 1 - 3 } Kontrol & 20 & 59,77 & & & \\
\hline
\end{tabular}

Model pembelajaran kooperatif tipe STAD mengkondisikan siswa dalam bentuk kelompok yang heterogen dilihat dari berbagai segi termasuk segi kemampuan awal. Kelompok atau tim yang dibentuk bertujuan untuk memudahkan siswa mendiskusikan permasalahan yang ditemui dalam proses pembelajaran. Dalam hal ini, penerapan model pembelajaran kooperatif tipe STAD dapat menjadikan siswa bersemangat untuk mengikuti proses pembelajaran.
Hal tersebut sejalan dengan pendapat Isjoni (2009:51) yang menyatakan bahwa STAD merupakan salah satu tipe kooperatif yang menekankan pada adanya aktivitas dan interaksi di antara siswa untuk saling memotivasi dan saling membantu dalam menguasai materi pelajaran guna mencapai prestasi yang maksimal. Isjoni menekankan bahwa dengan adanya interaksi antara siswa dalam kelompok akan memudahkan siswa tersebut dalam menyelesaikan masalah dalam pembelajaran.

Komponen pertama pembelajaran kooperatif tipe STAD adalah presentasi kelas. Presentasi dilakukan oleh guru bertujuan untuk memperkenalkan materi tentang menulis teks berita. Kegiatan selanjutnya adalah membentuk tim yang hetorogen. Tim atau kelompok terdiri dari siswa yang berkemampuan awal tinggi, menengah, dan rendah. Hal ini bertujuan agar semua kelompok dapat mempersiapkan anggotanya agar bisa memahami pembelajaran Menulis teks berita dengan baik. Permasalahan dalam tim atau kelompok didiskusikan secara bersama sehingga siswa anggota dapat memahaminya. Pada pembelajaran, siswa mendiskusikan materi yang berhubungan dengan menulis teks berita, di antaranya materi tentang pengertian berita, jenisjenis berita, kontruksi berita, dan syarat penulisan berita berdasarkan presentasi yang dilakukan guru dan contoh berita yang terdapat dalam bahan ajar.

Komponen selanjutnya adalah kuis. Kuis dapat dartikan sebagai tes yang diberikan kepada kelompok dan dikerjakan secara individual. Kuis tersebut diberikan setelah pembelajaran selesai. Siswa dalam kelompok boleh saling berdiskusi untuk mengatasi masalah yang dihadapi tetapi bukan untuk menyamakan jawaban tugas yang telah diberikan. Setiap pernyataan, tanggapan, dan jawaban yang dikemukakan oleh anggota kelompok dan 
diberikan poin oleh guru. Hal ini menjadikan siswa lebih bersemangat mengikuti proses pembelajaran. Poin yang dikumpulkan dikalkulasikan dan kelompok yang memiliki jumlah poin yang tertinggi diberi penghargaan. Tes yang diberikan kepada siswa adalah tes unjuk kerja menulis teks berita. Tes ini dilakukan untuk melihat pengaruh penerapan model pembelajaran kooperatif tipe STAD terhadap kemampuan menulis teks berita siswa di kelas VIII SMP Negeri 24 Jambi.

Proses pembelajaran pada kelas eksperimen menjadi efektif dari biasanya. siswa secara berkelompok aktif mendiskusikan permasalahan yang dikemukankan oleh guru. Selain itu, siswa juga termotivasi untuk mengungkapkan pendapat, pertanyaan, dan memberikan jawaban untuk mendapatkan poin kelompok. Pemahaman yang dimiliki sangat baik sehingga siswa mudah mamahami dan mengigat konsep-konsep y ang terkait dengan menulis teks berita.

Berbeda dengan model pembelajaran kooperatif tipe STAD, pembelajaran konvensional pembelajaran konvensional yang berpusat pada guru dan kegiatannya berfokus pada aktivitasaktivitas akademik untuk mengembangkan siswa dalam mengembangkan pengetahuan. Pembelajaran yang berorientasi kepada guru dengan tujuan agar siswa dapat dapat menguasai pelajaran secara maksimal. Hal ini sesuai dengan pendapat Djafar (2001:3) yang menyatakan bahwa metode belajar langsung merupakan metode yang berorientasi pada guru sehingga hampir seluruh kegiatan belajar mengajar dikendalikan oleh guru. Begitu juga dengan Suprihatiningrum (2013:229) yang menyatakan "Pembelajaran konvensional adalah model pembelajaran yang berpusat pada guru". Materi pelajaran sengaja diberikan secara langsung. Peran siswa dalam model pembelajaran ini adalah menyimak untuk menguasai materi pelajaran yang disampaikan oleh guru. Setelah pembelajaran berakhir, siswa diharapkan dapat memahaminya dengan benar dengan cara dapat mengungkapkan kembali materi yang telah diuraikan.

$$
\text { Komponen pertama pada }
$$

pembelajaran konvensional adalah menyampaikan dan menetapkan tujuan pembelajaran. Guru memberikan penjelasan tujuan pembelajaran serta mempersiapkan siswa untuk belajar. Tujuan langkah ini untuk menarik perhatian siswa serta memotivasi siswa agar berperan dalam pembelajaran. Selanjutnya, guru menyiapkan siswa, yaitu kegiatan yang bertujuan untuk menarik perhatian siswa, memusatkan perhatian siswa pada pokok pembicaraan, dan mengingatkan kembali pada kemampuan yang telah dimilikinya, yang relevan dengan pokok pembicaraan yang akan dipelajari.

Komponen kedua adalah mendemonstrasikan pengetahuan atau keterampilan. Saat mendemonstrasikan pengetahuan atau keterampilan oleh guru, yang perlu diperhatikan adalah kejelasan dalam melakukan dan menjelaskannya. Kunci untuk berhasil ialah mempresentasikan informasi sejelas mungkin dan mengikuti langkah-langkah demonstrasi yang efektif. Kejelasan dicapai melalui perencanaan dan pengorganisasian materi dengan struktur yang baik.

Komponen ketiga adalah memberikan latihan terbimbing. Pada tahap ini yang perlu diperhatikan adalah cara guru mempersiapkan dan melaksanakan "pelatihan terbimbing". Siswa diberikan kesempatan untuk melakukan latihan singkat dan bermakna tentang menulis teks berita. Selanjutnya, siswa diberikan pelatihan sampai benarbenar menguasai konsep/keterampilan yang dipelajari. Penugasan demikian 
ditandai oleh kemampuan siswa melakukan keterampilan secara otomatis.

Komponen keempat adalah mengecek pemahaman dan memberikan umpan balik. Fase ini mirip dengan apa yang disebut resitasi. Fase ini ditandai dengan pertanyaan-pertanyaan yang dilontarkan oleh guru kepada siswa dan siswa memberikan jawaban yang menurut pendapat mereka benar. Tugas paling penting bagi guru dalam menggunakan pembelajaran konvensional adalah memberikan siswa umpan balik yang bermakna dan pengetahuan tentang hasil latihan yang diperoleh siswa. Tanpa umpan balik yang spesifik, siswa tak mungkin dapat memperbaiki kekurangan atau kesalahannya dan tidak dapat mencapai tingkat penguasaan keterampilan yang mantap.

Dalam memberikan umpan balik, berikan batuan agar fokus perhatian siswa pada proses bukan pada hasil. Dengan demikian, siswa akan memahami bahwa hasil yang akan diperoleh bila proses sebaiknya diiringi dengan demonstrasi cara melakukan prosedur dengan benar. Tahapan langkah ini yang harus dijelaskan guru pada terhadap siswa. Selanjutnya, guru mendemonstrasikan tahap atau langkah yang bernar.

Komponen kelima adalah memberikan perluasan latihan mandiri. Bentuk latihan mandiri yang diberikan adalah tugas menulis teks berita secara bebas. Setelah selesai dilakukan latihan mandiri, siswa diberikan tes unjuk kerja menulis teks berita. Sama dengan tes unjuk kerja pada kelas eksperimen, tes ini dilakukan untuk mengetahui pengaruh penerapan pembelajaran konvensional terhadap kemampuan menulis teks berita siswa di kelas VIII SMP Negeri 24 Jambi

Berdasarkan apa yang dilihat ketika penelitian berlangsung, siswa kelas kontrol yang diajar dengan menerapkan pembelajaran konvensional cenderung kaku dan tidak bersemangat dalam pembelajaran. Siswa mendengarkan penjelasan dari guru, mencatat materi pelajaran, dan menjawab pertanyaan yang dikemukakan oleh guru tetapi siswa tidak termotivasi untuk bertanya, apalagi menemukan sendiri konsep-konsep yang terkait dengan materi pelajaran. Siswa juga tidak terdorong untuk bertanya dengan siswa yang lainnya. Jika materi yang disampaikan guru sudah mulai membosankan, siswa lebih cenderung acuh tak acuh, ada yang mengobrol bahkan bercanda dengan menggangu temannya.

Begitu juga pada saat tes berlangsung, siswa pada kelas kontrol sangat berbeda dibandingkan siswa pada kelas eksperimen. Seluruh siswa memang mengerjakan tes yang diberikan, akan tetapi tidak begitu antusias atu bersemangat. Mereka mengerjakan dengan apa adanya sesuai dengan kemampuan mereka masing-masing.

Berdasarkan uraian tersebut, dapat disimpulkan bahwa hasil tes unjuk kerja menulis teks berita siswa kelas eksperimen yang diajar dengan model pembelajaran kooperatif tipe STAD lebih baik daripada hasil tes unjuk kerja menulis teks berita siswa yang diajar dengan pembelajaran konvensional. Hasil temuan penelitian dan analisis data menunjukkan bahwa model pembelajaran kooperatif tipe STAD memberikan pengaruhterhadap kemapuan menulis teks berita.

Untuk menguatkan hasil penelitian ini, berikut akan diuraikan beberapa penelitian dari beberapa negara yang menyatakan bahwa kemampuan yang menggunakan model pembelajaran kooperatif tipe STAD selalu lebih baik. Pertama, penelitian Khan (2011:213) menunjukkan hasil tes kelompok eksperimen diajarkan dengan metode STAD lebih baik daripada kelompok kontrol yang diajarkan dengan metode ceramah tradisional. Hal itu didapat berdasarkan hasil uji-t, nilai yang 
diperoleh adalah 0,72904. Itu berarti $t_{\text {hitung }}$ lebih rendah dari $t_{\text {tabel }}$ dengan taraf signifikansi 2.07. Maka hasilnya menunjukkan bahwa perbedaan dalam prestasi antara kedua kelompok diajarkan dengan metode ceramah tradisional dan metode pembelajaran kooperatif tidak signifikan.

Kedua, penelitian Alijanian (2012:1971) menunjukkan hasil tes prestasi bahasa Inggris kelompok eksperimen yang diajarkan dengan model STAD lebih unggul daripada kelompok kontrol yang diajarkan dengan metode ceramah tradisional. Selama dua bulan, perbedaan antara kedua kelompok eksperimen dan kontrol dalam post test adalah 2,58, dengani perbedaan rata-rata signifikan secara statistik $(\mathrm{p}=0,001)$.

Ketiga, hasil penelitian Ibraheem (2011:16) menunjukkan bahwa perlakuan model STAD di kelas dapat meningkatkan kemampuan siswa. Hal ini dikaitkan dengan fakta bahwa siswa dalam STAD dengan kelompok kompetisi melakukan semua latihan belajar bersama-sama selama tahap pembelajaran (yaitu mengisi lembar kerja dan menjawab pertanyaan kuis). Hal ini ditambah dengan persaingan yang sehat dengan anggota tim lain mungkin mungkin bertanggung jawab untuk siswa menunjukkan sikap yang lebih positif daripada siswa dalam kelompokkelompok lainnya.

Keempat, hasil penelitian

Amornsinlaphachai $\quad$ (2014:433-434) menunjukkan bahwa penggunaaan model pembelajaran kooperatif tipe STAD dapat mengurang kelemahan pesta didik dalam belajar. Hasil tersebut diperoleh dari evaluasi beberapa ahli yang menjelaskan bahwa model yang digunakan sesuai dengan prinsip-prinsip dan teori, model yang digunakan terkenal dan menguntungkan, dan teori yang digunakan sebagai fundamental merancang titik model untuk kesesuaian media menggunakan. Maka dari itu, para ahli menerima model tersebut dengan nilai $70,27 \%$ secara keseluruhan.

Kelima, hasil penelittian Tran (2013:9) menunjukkan bahwa tidak ada perbedaan yang signifikan secara statistik dalam skor pre-test matematika dari kelompok eksperimen $\quad(\mathrm{M}=7.48$, $\mathrm{SD}=1,107, \mathrm{~N}=36$ ) dan kelompok kontrol $(\mathrm{M}=7.60, \mathrm{SD}=1,105, \mathrm{~N}=38), \mathrm{t}(72)=-.485$, $\mathrm{p}=0,629$. Namun, temuan yang diperoleh dari uji-t pada skor post-test matematika menunjukkan bahwa skor rata-rata kelompok perlakuan $(\mathrm{M}=8.45, \mathrm{SD}=0,778)$ secara statistik signifikan lebih tinggi $(\mathrm{t}=2,685, \mathrm{df}=58,498$, dua tailed, $\mathrm{p}=0,007)$ dibandingkan kelompok kontrol $(\mathrm{M}=8,01$, $\mathrm{SD}=0,860$ ). Maka dari itu, dapat disimpulkan bahwa kelas yang diperlakukan dengan model pembelajaran STAD menghasilkan peningkatan skor pada secara keseluruhan lebih tinggi dibanding kelas tanpa perlakuan.

Keenam, hasil penelitian Wang (2009:119) menunjukkan bahwa siswa pada kelas yang diberi perlakuan termotivasi dalam belajar untuk mendengarkan dan berbicara, hubungan interpersonal, dan termotivasi bekerja sama untuk untuk mencapai tujuan. Selanjutnya, dalam kelas belajar kooperatif, siswa memiliki banyak pengalaman; siswa lebih termotivasi untuk bekerja lebih keras, menciptakan suasana yang positif, di mana pembelajaran itu diperoleh dan dibahas secara interaktif

Ketujuh, tujuan penelitian Yeung (2015:37) adalah untuk mengetahui perkembangan model STAD dalam dua dekade. Yeung menyoroti munculnya model STAD berdasarkan isu-isu utama, perdebatan, dan investigasi terbaru mengenai efe ktivitas, keterjangkauan, dan kepraktisan. Ada lima penelitian tentang STAD yang menjadi kajian evaluasi oleh Yeung, yaitu (1) Pertama, hasil penelitian Ghazi pada tahun 2001 yang 
menunjukkan bahwa sebagian besar siswa menyetujui STAD karena kegunaannya, kualitas menyenangkan, kelayakan, dan kejelasan. Dengan demikian, strategi ini sangat dianjurkan. (2) Hasil penelitian Ghazi pada tahun 2004 yang menunjukkan bahwa sikap stakeholders terhadap STAD mempengaruhi pelaksanaannya. (3) Hasil penelitian Khan \& Inamullah di Pakistan pada tahun 2011 yang menunjukkan kelompok eksperimen yang diberi perlakuan STAD lebih baik dibandingkan dengan kelompok kontrol, tetapi rasa ingin tahu prestasi mereka yang acuh tak acuh. (4) Hasil penelitian Van Wyk pada tahun 2010 di Universitas Afrika Selatan, yang menunjukkan peningkatan yang signifikan tercermin dari hasil pre-tes dan post-test pada kelas yang diberi perlakuan STAD dibandingkan dengan kelompok kontrol.

(5) Hasil penelitian Gillies pada tahun 2004 di Australia yang menunjukkan bahwa siswa dalam kelompok STAD terstruktur lebih bersedia untuk mendengarkan, meminta elaborasi, berbagi ide, dan memberikan bantuan bila dibandingkan dengan kelas STAD tidak terstruktur.

Berdasarkan hasil penelitian dari berbagai negara di atas dapat disimpulkan bahwa model pembelajaran kooperatif tipe STAD selalu menciptakan perubahan dari variabel yang diuji. Dari berbagai penelitian yang dilakukan dengan menggunakan model pembelajaran tipe STAD, hasil penelitiannya selalu menunjukkan perubahan. Hal ini menunjukkan bahwa model pembelajaran yang dikembangkan Slavin ini baik untuk diterapkan dalam pembelajaran di kelas.

\section{b. Kemampuan Menulis Teks Berita Siswa Berkemampuan Awal Tinggi yang Diajar Menggunakan Model Kooperatif Tipe STAD dan Pembelajaran Konvensional}

Pengujian hipotesis kedua menunjukkan hasil yang menyatakan bahwa kemampuan menulis teks berita siswa berkemampuan awal tinggi pada kelas eksperimen yang diajar dengan model pembelajaran kooperatif tipe STAD lebih baik daripada kemampuan menulis teks berita pada siswa berkemampuan awal tinggi pada kelas kontrol yang diajar dengan pembelajaran konvensional. Hal ini terlihat dari hasil perhitungan uji hipotesis yang menunjukkan $t_{\text {hitung }}=$ 15,327 dan $t_{\text {tabel }}=1,720$ pada taraf nyata 0,05 . Hasil tersebut menunjukkan bahwa $t_{\text {hitung }}>\mathrm{t}_{\text {tabel }}$ yang berarti $\mathrm{H}_{0}$ ditolak dan $\mathrm{H}_{1}$ diterima. Untuk lebih jelasnya dapat dilihat pada tabel berikut.

Tabel 2. Hasil Uji Hipotesis Tes Kemampuan Menulis Teks Berita Siswa Berkemampuan Awal Tinggi yang Diajar Menggunakan Model Kooperatif Tipe STAD dan Pembelajaran konvensional

\begin{tabular}{|l|c|c|cc|c|}
\hline \multicolumn{1}{|c|}{ Kelas } & $\mathbf{N}$ & $\overline{\boldsymbol{x}}$ & $\mathbf{t}_{\text {hitung }}$ & $\mathbf{D f}$ & $\mathbf{t}_{\text {tabel }}$ \\
Eksperimen & 11 & 73,92 & & & \\
\cline { 1 - 3 } Kontrol & 10 & 63,22 & & 19 & 1,720 \\
\hline
\end{tabular}

Pada kelas eksperimen, model pembelajaran kooperatif tipe STAD mampu memberikan pengaruh terhadap kemampuan menulis teks berita siswa berkemampuan awal tinggi. Hal ini sesuai dengan prinsip pembelajaran kooperatif seperti yang dikemukakan Asma (2012:6), yang menyatakan "Pembelajaran koperatif paling tidak berisi lima prinsip pembelajaran, yaitu prinsip belajar siswa aktif, belajar kerjasama, belajar patriotik, mengajar reaktif, dan pembelajaran menyenangkan". Mereka harus lebih aktif dibandingkan siswa yang berkemampuan rendah. Hal itu dikarenakan siswa yang berkemampuan awal tinggi mampu membantu teman sekelompoknya dalam menyelesaikan masalah. Selain itu, siswa dituntut untuk dapat aktif dalam kelompok, mendiskusikan permasalahan 
dan menjawab pertanyaan. Kegiataan tersebut melibatkan siswa secara aktif sehingga siswa yang berkemampuan awal tinggi lebih dapat menyelesaikan tugas yang diberikan dengan baik.

Begitu pula halnya pada kelas kontrol, kemampuan awal tinggi juga mempengaruhi kemampuan siswa dalam menulis teks berita. Siswa yang memiliki kemampuan awal tinggi akan merasa tertantang untuk dapat menulis teks berita dengan baik. Mereka terdorong untuk menulis teks berita dengan baik. Siswa yang berkemampuan awal tinggi lebih mampu menemukan ide, mewujudkan ide dalam bentuk tulisan, dan menyusunnya menjadi sebuah teks berita yang baik. Walaupun demikian, siswa berkemampuan awal tinggi pada kelas kontrol bekerja berdasarkan kemampuannya sendiri. Artinya, teori yang didapatnya dari guru tidak didiskusikan lagi dengan dengan temannya. Walau ada beberapa siswa yang bertanya dengan guru dan temannya tetapi secara umum mereka cenderung bekerja sendiri.

Berdasarkan uraian di atas dapat disimpulkan bahwa hasil tes kemampuan menulis teks berita siswa berkemampuan awal tinggi yang diajar dengan model pembelajaran kooperatif tipe STAD lebih baik dari siswa berkemampuan awal tinggi yang diajar dengan pembelajaran konvensional. Hasil penelitian dan analis is data menunjukkan bahwa model pembelajaran kooperatif tipe STAD memberikan pengaruh terhadap kemapuan menulis teks berita siswa yang memiliki kemampuan awal tinggi.

c. Kemampuan Menulis Teks Berita Siswa Berkemampuan Awal Rendah yang Diajar Menggunakan Model Kooperatif Tipe STAD dan Pembelajaran Konvensional

Pengujian hipotesis ketiga menunjukkan hasil yang menyatakan bahwa kemampuan menulis teks berita siswa berkemampuan awal rendah pada kelas eksperimen yang diajar dengan model pembelajaran kooperatif tipe STAD lebih baik daripada kemampuan menulis teks berita siswa berkemampuan awal rendah pada kelas kontrol yang diajar dengan pembelajaran konvensional. Hal ini terlihat dari hasil perhitungan hipotesis yang menunjukan $t_{\text {hitung }} 15,327$ dan $t_{\text {tabel }}$ 1,720 pada taraf nyata 0,05 . Hasil penghitungan tersebut menunjukkan bahwa $\mathrm{H}_{1}$ diterima karena $t_{\text {hitung }}>\mathrm{t}_{\text {tabel }}$. Untuk lebih jelasnya dapat dilihat pada tabel berikut.

Tabel 3. Hasil Uji Hipotesis Tes Kemampuan Menulis Teks Berita Siswa Berkemampuan Awal Rendah yang Diajar Menggunakan Model Kooperatif Tipe STAD dan Pembelajaran konvensional

\begin{tabular}{|c|c|c|c|c|c|}
\hline Kelas & $\mathbf{N}$ & $\bar{x}$ & $\mathbf{t}_{\text {hitung }}$ & Df & $\mathbf{t}_{\text {tabel }}$ \\
\hline Eksperimen & 11 & 73,92 & \multirow{2}{*}{15,327} & \multirow{2}{*}{19} & \multirow{2}{*}{1,720} \\
\hline Kontrol & 10 & 63,22 & & & \\
\hline
\end{tabular}

pembelajaran kooperatif tipe STAD mampu memberikan pengaruh terhadap kemampuan menulis teks berita siswa berkemampuan awal rendah. Siswa bertukar pikiran dengan siswa yang memiliki kemampuan yang lebih tinggi. Hal itu dikarenakan dalam pembelajaran kooperatif tipe STAD, siswa yang berkemampuan awal tinggi mampu membantu teman sekelompoknya yang berkemampuan rendah dalam menyelesaikan masalah. Selain itu, dalam pembelajaran kooperatif, siswa dituntut untuk dapat aktif dalam kelompok, menemukan dan mendiskusikan permasalahan, menjawab pertanyaan. Kegiataan tersebut secara langsung melibatkan siswa berkemampuan awal rendah sehingga mereka menjadi lebih aktif dan bersemangat untuk dapat menyelesaikan tugas yang diberikan. Maka dari itu, siswa yang berkemampuan 
awal rendah akan lebih termotivasi juga untuk meningkatkan poin kelompoknya. Walau demikian, pada saat mengerjakan tes yang diberikan, mereka harus bekerja sendiri sesuai dengan kemampuannya masing.

Sama halnya dengan kelas eksperimen, pada kelas kontrol, kemampuan awal juga mempengaruhi kemampuan siswa dalam menulis teks berita. Siswa yang memiliki kemampuan awal rendah cenderung tidak tertarik mengikuti proses pembelajaran dan kurang bersemangat untuk dapat menulis teks berita dengan baik. Pada dasaranya mereka tetap mengerjakan tugas yang diberikan, tetapi siswa yang berkemampuan awal rendah kurang bersemangat mencari dan menemukan ide, kurang mewujudkan ide dalam bentuk tulisan. Selain itu, siswa berkemampuan awal rendah bekerja berdasarkan kemampuannya sendiri. Artinya, teori yang didapatnya dari guru tidak didiskusikan lagi dengan dengan temannya. Sesuai dengan kemampuan awalnya, secara umum mereka tidak mau menanyakan kembali masalah yang mereka hadapi, baik kepada guru maupun kepada temannya.

Berdasarkan uraian di atas, dapat disimpulkan bahwa hasil tes kemampuan menulis teks berita siswa berkemampuan awal rendah yang diajar dengan model pembelajaran kooperatif tipe STAD lebih baik dari siswa berkemampuan awal rendah yang diajar dengan pembelajaran konvensional. Hasil penelitian dan analis is data menunjukkan bahwa model pembelajaran kooperatif tipe STAD memberikan pengaruh dan dampak positif terhadap kemapuan menulis teks berita siswa yang memiliki kemampuan awal rendah. Hal ini terbukti dari perbedaan hasil tes unjuk kerja siswa berkemampuan awal rendah pada kelas eksperimen dan siswa berkemampuan awal rendah pada kelas kontrol.

\section{d. Interaksi Model Pembelajaran Kooperatif Tipe STAD dan Kemampuan Awal Terhadap Keterampilan Menulis Teks Berita Siswa}

Hasil perhitungan anava dua arah untuk pengujian hipotesis keempat menunjukkan bahwa tidak terdapat interaksi antara model pembelajaran kooperatif tipe STAD dengan kemampuan awal terhadap kemampuan menulis teks berita. Hal ini dikarenakan signifikansi pada baris interaksi adalah 0,901 lebih besar dari taraf nyata $(0,05)$, berarti $\mathrm{H}_{0}$ diterima. Hal tersebut menunjukkan bahwa model pembelajaran kooperatif tipe STAD secara independen tidak mempengaruhi kemampuan menulis teks berita. Dengan kata lain tidak terdapat pengaruh dari interaksi model pembelajar kooperatif tipe STAD terhadap kemampuan menulis teks berita. Banyak faktor lain yang dapat menjadi penunjang kemampuan berita menulis teks berita. Misalnya, guru selaku pengampu mata pelajaran, situasi kelas yang kondusif, latar belakang siswa dan lain-lain.

Tabel 4. Hasil Uji Hipotesis Interaksi Model Pembelajaran Kooperatif Tipe STAD dan Kemampuan Awal Terhadap Keterampilan Menulis Teks Berita Siswa

\begin{tabular}{|l|c|c|c|c|c|}
\hline $\begin{array}{l}\text { Sumber } \\
\text { Keragaman }\end{array}$ & $\begin{array}{c}\text { Jumlah } \\
\text { Kuad rat }\end{array}$ & df & $\begin{array}{c}\text { Kuadrat } \\
\text { Tengah }\end{array}$ & F & Sig. \\
\hline $\begin{array}{l}\text { M odel } \\
\text { Pembelajaran }\end{array}$ & 1285,491 & 1 & 1285,49 & 50,468 & 0,000 \\
\hline $\begin{array}{l}\text { Kemampuan } \\
\text { Awal }\end{array}$ & 390,400 & 1 & 390,40 & 15,327 & 0,000 \\
\hline Interaks & 0,400 & 1 & 0,400 & 0,16 & 0,901 \\
\hline Galat & 967,918 & 38 & 25,472 & & \\
\hline Total & $\begin{array}{l}185332,00 \\
\text { Dengan tidak }\end{array}$ & \multicolumn{4}{|c|}{ adanya interaksi }
\end{tabular}
antara model pembelajaran kooperatif tipe STAD dan kemampuan awal terhadap kemampuan menulis teks berita berarti masing-masing faktor dari model pembelajaran kooperatif STAD tidak begantung satu sama lain dalam mempengaruhi kemampuan menulis teks 
berita siswa, baik di kelas eksperimen maupun kelas kontrol.

\section{SIMPULAN}

Berdasarkan hasil penelitian, dapat disimpulkan bahwa model pembelajaran kooperatif tipe STAD mempengaruhi kemampuan menulis teks berita. Pengaruh tersebut dapat dijelaskan sebagai berikut. Pertama, kemampuan menulis teks berita siswa yang diajar dengan model pembelajaran kooperatif tipe STAD lebih baik daripada kemampuan menulis teks berita siswa yang diajar dengan pembelajaran konvensional. Kedua, kemampuan menulis teks berita siswa berkemampuan awal tinggi yang diajar dengan model pembelajaran kooperatif tipe STAD lebih baik daripada kemampuan menulis teks berita siswa berkemampuan awal tinggi yang diajar dengan pembelajaran konvensional. Ketiga, kemampuan menulis teks berita siswa berkemampuan awal rendah yang diajar dengan model pembelajaran kooperatif tipe STAD lebih baik daripada kemampuan menulis teks berita siswa berkemampuan awal rendah yang diajar dengan pembelajaran konvensional. Keempat, tidak terdapat interaksi antara model pembelajaran kooperatif tipe STAD dan kemampuan awal terhadap kemampuan menulis teks berita.

\section{SARAN}

Berdasarkan simpulan yang telah dikemukakan di atas, terbukti bahwa model pembelajaran kooperatif tipe STAD dapat dijadikan alternatif untuk meningkatkan kemampuan menulis teks berita. Untuk itu, dapat dikemukakan beberapa saran sebagai berikut. Pertama, agi guru Bahasa Indonesia khususnya guru SMP Negeri 24 Jambi untuk dapat menggunakan model pembelajaran dalam pembelajaran menulis teks berita, maupun pada pembelajaran lainnya. Kedua, model pembelajaran kooperatif tipe STAD dapat dijadikan sebagai alternatif dalam pembelajaran menulis teks berita karena siswa terlibat aktif dalam proses pembelajaran yang diberikan. Ketiga, kepada peneliti selanjutnya agar melakukan penelitian yang lebih mendalam tentang model pembelajaran kooperatif tipe STAD pada pokok bahasan lain yang diajarkan di sekolah.

\section{DAFTAR RUJUKAN}

Alijanian, E. (2012). The effect of student teams achievement division technique on English achievement of Iranian EFL learners. Theory and Practice in Language Studies, 2 (9), 1971-1975.

Amornsinlaphachai, P. (2014). Designing a learning model using the STAD technique with a suggestion system to decrease learners' weakness. Procedia - Social and Behavioral Sciences 116 (2014), $431-435$.

Asma, N. (2012). Model Pembelajaran Kooperatif. Padang: UNP Press.

Chaer, A. (2010). Bahasa Jurnalistik. Jakarta:Rineka Cipta.

Djafar, T. Z. (2001). Kontribusi Strategi Pembelajaran Terhadap Kemampuan. Universitas Negeri Padang.

Ibraheem, T.L. (2011). Effects of two modes of student teamsachievement division strategies on senior secondary school students' learning outcomes in chemical kinetics. Asia-Pacific Forum on Science Learning and Teaching, 12 (7), 1-20.

Ibrahim, and Sudjana, N. (2009). Penelitian dan Penilaian Pendidikan. Bandung: Sinar Baru Algensindo.

Isjoni. (2009). Cooperative Learning: Efektifitas Pembelajaran Kelompok. Bandung: Alfabeta. 
Khan, G. N. (2011). Effect of student's team achievement division (STAD) on academic achievement of students. Asian Social Science, 7 (12), 211-215.

Nurgiyantoro, B. (2014). Penilaian Pembelajaran Bahasa Berbasis Kompetensi. Yogyakarta: BPFE.

Semi, M.A. (2007). Dasar-dasar Keterampilan Menulis. Bandung: Angkasa.

Slavin, R. (2005). Cooperative Learning Teori, Riset dan Praktik (terjemahan). Bandung: Nusa Media.

Sugiyono. (2010). Metode Penelitian Pendidikan Pendekatan Kuantitatif, Kualitatif dan $R \& D$. Bandung: Alfabeta.

Sudjana, N. (2010). Penilaian Hasil Proses Belajar Mengajar. Bandung: PT Remaja Rosdakarya.

Suprihatiningrum, J. (2013). Strategi Pembelajaran: Teori \& Aplikasi. Yogakarta: Ar-ruzz Media.

Tran, V. D. (2013). Effect of student team achievement division (STAD) on academic, and attitudes of grade 9th secondary scholl students towards mathematics. International Journal of Sciences, 2 (4), 5-15.

Usman, H., and Akbar, R. P. S. (2006). Pengantar Statistika. Edisi Kedua.Jakarta: Bumi Aksara.

Wang, T.P. (2009). Applying Slavin's cooperative learning techniques to a college EFL conversation class. The Journal of Human Resource and Adult Learning, 5 (1), 112120.

Yeung, H. C. H. (2015). Literature review of the cooperative learning strategy-student team achievement division (STAD). International Journal of Education, 7 (1), 2843. 